\title{
Bulk Glass Formation of Ti-Zr-Hf-Cu-M (M=Fe, Co, Ni) Alloys
}

\author{
Liqun $\mathrm{Ma}^{1}$, Limin Wang ${ }^{2}$, Tao Zhang ${ }^{1}$ and Akihisa Inoue ${ }^{1}$ \\ ${ }^{1}$ Institute for Materials Research, Tohoku University, Sendai 980-8577, Japan \\ ${ }^{2}$ Inoue Superliquid glass Project, ERATO, JST, Sendai 982-0807, Japan
}

The glass-forming ability of Ti-Zr-Hf-Cu-M $(\mathrm{M}=\mathrm{Fe}, \mathrm{Co}, \mathrm{Ni})$ alloys was examined by melt-spinning and copper mold casting methods. New $\mathrm{Ti}_{20} \mathrm{Zr}_{20} \mathrm{Hf}_{20} \mathrm{Cu}_{20} \mathrm{Ni}_{20}$ bulk glassy rod of $1.5 \mathrm{~mm}$ in diameter was formed by copper mold casting. The $T_{\mathrm{x}}$ and $T_{\mathrm{g}}$ of the glassy rod were $711 \mathrm{~K}$ and $658 \mathrm{~K}$ and $T_{\mathrm{g}} / T_{\mathrm{m}}$ was 0.57 . The bulk glassy alloy can be characterized by equal concentration of constituent elements without distinct host component. It is confirmed that more multicomponent glassy systems have a better glass-forming ability as compared with simpler alloy systems. The glassy alloy rod also exhibits good mechanical properties which are similar to those for ordinary glassy alloys. The finding of this alloy system may provide a new synthesis method of bulk glassy alloys.

(Received December 3, 2001; Accepted December 27, 2001)

Keywords: bulk glassy alloy, glass-forming ability, copper mold casting, mechanical properties

\section{Introduction}

Since the first success of a bulk glassy alloy in La-Al-Ni system in $1989,{ }^{1)}$ much attention has been paid to the development of alloy systems with high glass-forming ability (GFA), with which a glassy state can be prepared with relatively lower cooling rates. The high glass-forming ability enables us to prepare bulk glassy alloys by copper mold casting or quenching the melt in a quartz tube into stirred water. As a result, a number of bulk glassy alloys have been successfully prepared in multicomponent systems such as $\mathrm{Mg}_{-},{ }^{2}$ ) $\mathrm{Zr}-,{ }^{3)} \mathrm{Ti}-,{ }^{4)} \mathrm{Fe}-,{ }^{5)} \mathrm{Pd}-,{ }^{6)} \mathrm{Ni}-,{ }^{7)} \mathrm{Co}-{ }^{8)}$ and $\mathrm{Cu}-{ }^{9)}$ based alloys. Summarizing the features of the above-mentioned multicomponent systems, the following three empirical rules have been proposed, ${ }^{10)}$ i.e., (1) multi-component systems consisting of more than three kinds of elements, (2) significant difference in atomic size ratios above $12 \%$ among the main constituent elements, and (3) suitable negative heats of mixing among their main elements. The thermal stability of a glassy alloy is usually examined by differential scanning calorimetry (DSC). The DSC curves of the bulk glassy alloys are featured by the glass transition before crystallization. It has been found that the values of $\Delta T_{\mathrm{x}}\left(\Delta T_{\mathrm{x}}=T_{\mathrm{x}}-T_{\mathrm{g}}\right)$ and $T_{\mathrm{g}} / T_{\mathrm{m}}$ are related to the glass-forming ability, where $T_{\mathrm{g}}, T_{\mathrm{x}}$ and $T_{\mathrm{m}}$ represent the glass transition, crystallization onset and melting temperatures, respectively. There is a tendency for glass-forming ability to increase with increasing $\Delta T_{\mathrm{x}}$ and $T_{\mathrm{g}} / T_{\mathrm{m}} \cdot{ }^{11)}$

For higher-order multicomponent glassy systems, it seems more difficult for the concentrations of all elements to simultaneously satisfy the composition requirements of crystalline phase than for lower-order systems. The crystallization process of the multicomponent supercooled liquid tends to become sluggish. Therefore, multicomponent alloy systems are expected to exhibit better GFA than that for the simple alloy systems. This is the well-known argument called "confusion principle". ${ }^{12)}$ This argument has also been quantified that, for a multicomponent system consisting of $n$ components with equal concentration, the probability of forming a critical nucleus of the required composition is reduced by an order of magnitude with the addition of each new com- ponent. ${ }^{13)}$ That is, the higher the complexity of alloy components, the higher is the GFA. The previously developed alloy systems with high GFA contain at least one main component with concentrations of over 40 at $\%$. Consequently, we have a question whether or not a bulk glassy alloy is formed in a system where a host component of more than 40 at $\%$ is not concluded and each concentration of constituent elements is not over 30 at $\%$, i.e., is there a non-based glassy system? If so, it may be a new method of synthesizing a bulk glassy alloy. In the present report, we have examined the thermal stability and glass forming ability of the Ti-Zr-Hf-Cu-M (M=Fe, Co, Ni) alloys, where the concentration of each constituent element is 20 at\%. We have also examined the possibility of forming a bulk glassy alloy in this system.

\section{Experimental Procedure}

$\mathrm{Ti}-\mathrm{Zr}-\mathrm{Hf}-\mathrm{Cu}-\mathrm{M}(\mathrm{M}=\mathrm{Fe}, \mathrm{Co}, \mathrm{Ni})$ alloys were prepared by arc melting the mixtures of pure metals in an argon atmosphere. Ribbon samples with a cross section of $0.02 \times$ $1.0 \mathrm{~mm}^{2}$ were prepared by melt-spinning. Bulk alloys in a rod form with diameters of $1,1.5$ and $2 \mathrm{~mm}$ were prepared by copper mold casting. Glassy structure of the bulk alloy rods was identified by X-ray diffraction and optical microscopy. Thermal stability associated with $T_{\mathrm{g}}$ and $T_{\mathrm{x}}$ was examined by differential scanning calorimetry (DSC) at a heating rate of $0.67 \mathrm{~K} / \mathrm{s}$. $T_{\mathrm{m}}$ was determined by differential thermal analysis (DTA) at a heating rate of $0.17 \mathrm{~K} / \mathrm{s}$. Compressive fracture strength was measured with an Instron-type testing machine at a strain rate of $8.3 \times 10^{-4} \mathrm{~s}^{-1}$ at room temperature. The gauge dimension was $1.5 \mathrm{~mm}$ in diameter and $3 \mathrm{~mm}$ in height. Fracture surface was examined by scanning electron microscopy (SEM). Hardness was measured with a Vickers hardness indenter under a load of $0.245 \mathrm{~N}$.

\section{Results and Discussion}

Figure 1 shows the XRD patterns of the melt-spun $\mathrm{Ti}_{20} \mathrm{Zr}_{20} \mathrm{Hf}_{20} \mathrm{Cu}_{20} \mathrm{M}_{20}(\mathrm{M}=\mathrm{Fe}, \mathrm{Co}, \mathrm{Ni})$ ribbons. Only broad peaks are seen, indicating that all the ribbons are in a sin- 


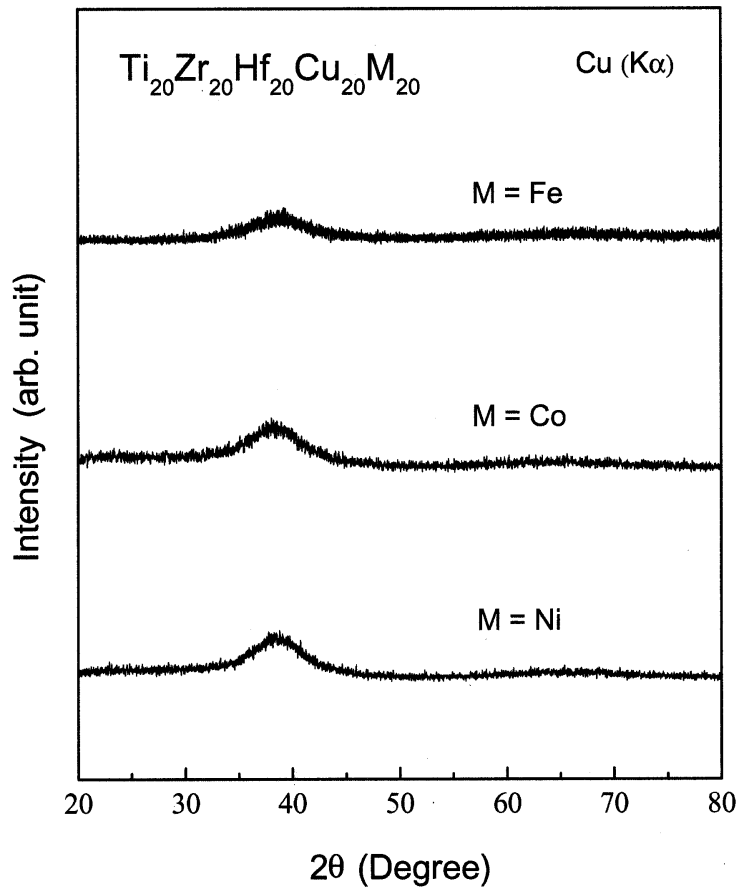

Fig. 1 XRD patterns of melt-spun $\mathrm{Ti}_{20} \mathrm{Zr}_{20} \mathrm{Hf}_{20} \mathrm{Cu}_{20} \mathrm{M}_{20}(\mathrm{M}=\mathrm{Fe}, \mathrm{Co}, \mathrm{Ni})$ ribbons.

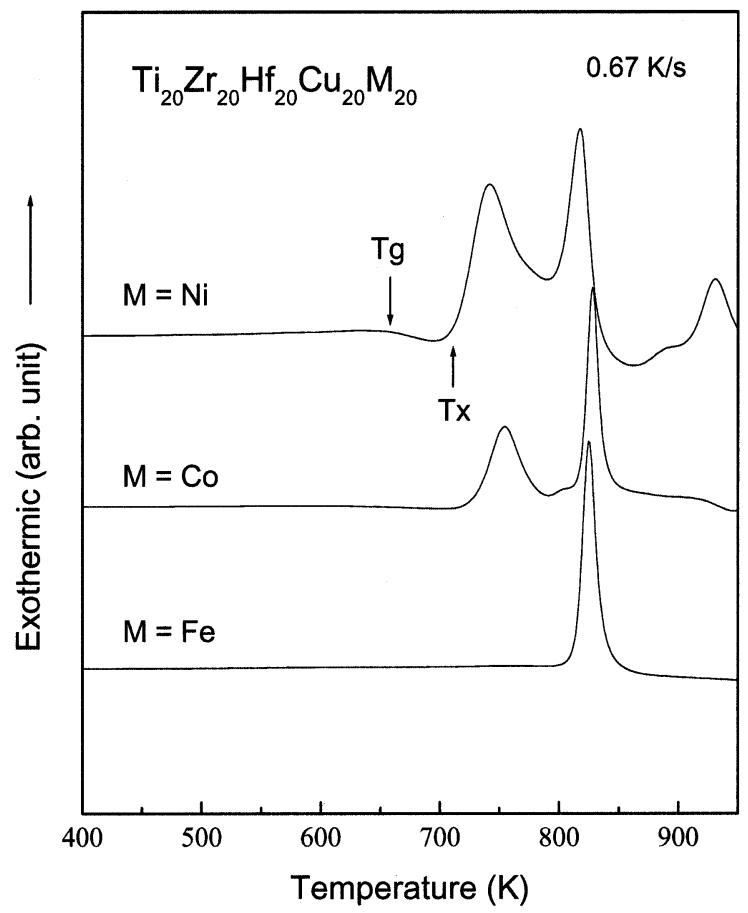

Fig. 2 DSC curves of melt-spun $\mathrm{Ti}_{20} \mathrm{Zr}_{20} \mathrm{Hf}_{20} \mathrm{Cu}_{20} \mathrm{M}_{20}(\mathrm{M}=\mathrm{Fe}, \mathrm{Co}, \mathrm{Ni})$ ribbons.

gle amorphous state. Figure 2 shows the DSC curves of the amorphous $\mathrm{Ti}_{20} \mathrm{Zr}_{20} \mathrm{Hf}_{20} \mathrm{Cu}_{20} \mathrm{M}_{20}(\mathrm{M}=\mathrm{Fe}, \mathrm{Co}, \mathrm{Ni})$ ribbons. It is noticed that a glass transition marked with $T_{\mathrm{g}}$, followed by a supercooled liquid region, is observed in the temperature range before crystallization for the $\mathrm{Ti}_{20} \mathrm{Zr}_{20} \mathrm{Hf}_{20} \mathrm{Cu}_{20} \mathrm{Ni}_{20}$ alloy. There is no appreciable glass transition for both the $\mathrm{Ti}_{20} \mathrm{Zr}_{20} \mathrm{Hf}_{20} \mathrm{Cu}_{20} \mathrm{Co}_{20}$ and the $\mathrm{Ti}_{20} \mathrm{Zr}_{20} \mathrm{Hf}_{20} \mathrm{Cu}_{20} \mathrm{Fe}_{20}$ alloys. The DTA curves indicating the melting points $\left(T_{\mathrm{m}}\right)$ of the three melt-spun alloys are shown in Fig. 3. From Figs. 2 and $3, T_{\mathrm{g}}, T_{\mathrm{x}}, \Delta T_{\mathrm{x}}, T_{\mathrm{m}}$ and $T_{\mathrm{g}} / T_{\mathrm{m}}$ are $658 \mathrm{~K}, 711 \mathrm{~K}, 53 \mathrm{~K}$,

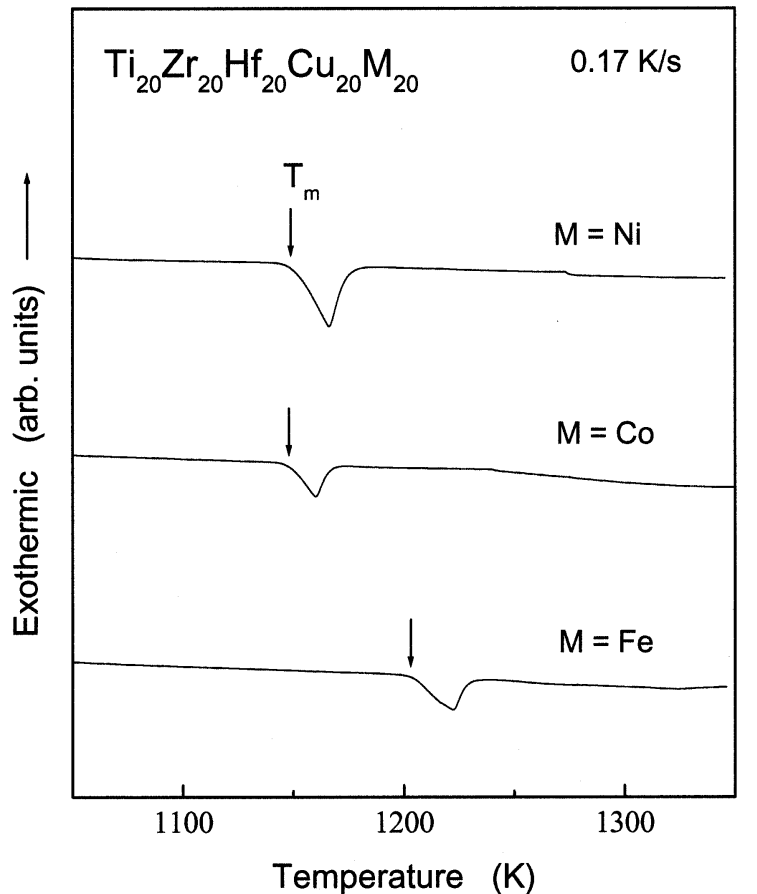

Fig. 3 DTA curves of melt-spun $\mathrm{Ti}_{20} \mathrm{Zr}_{20} \mathrm{Hf}_{20} \mathrm{Cu}_{20} \mathrm{M}_{20}(\mathrm{M}=\mathrm{Fe}, \mathrm{Co}, \mathrm{Ni})$ ribbons.

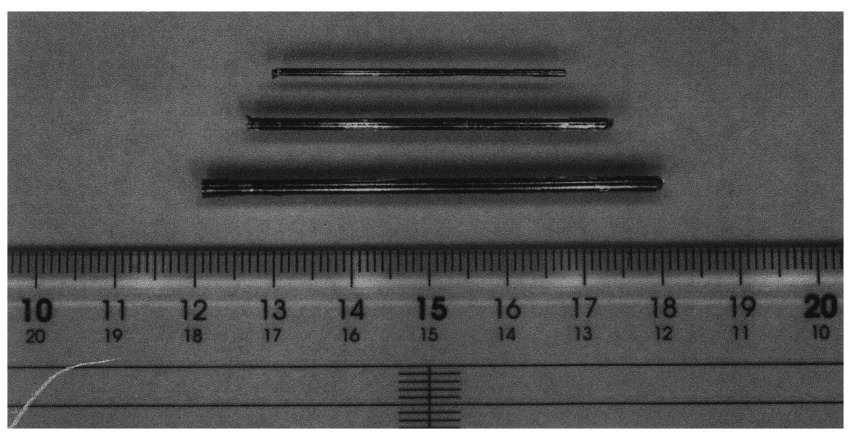

Fig. 4 Shape and outer surface of cast $\mathrm{Ti}_{20} \mathrm{Zr}_{20} \mathrm{Hf}_{20} \mathrm{Cu}_{20} \mathrm{Ni}_{20}$ rod samples with diameters of $1,1.5$ and $2 \mathrm{~mm}$.

$1149 \mathrm{~K}$ and 0.57 for the $\mathrm{Ti}_{20} \mathrm{Zr}_{20} \mathrm{Hf}_{20} \mathrm{Cu}_{20} \mathrm{Ni}_{20}$ amorphous alloy. This alloy is concluded to have a higher glass-forming ability than the other two alloys. We have tried to prepare bulk glassy samples of the Ni-containing alloy by the casting process. Figure 4 shows the outer surface appearance of the cast $\mathrm{Ti}_{20} \mathrm{Zr}_{20} \mathrm{Hf}_{20} \mathrm{Cu}_{20} \mathrm{Ni}_{20}$ samples of $1,1.5$ and $2 \mathrm{~mm}$ in diameter. Figure 5 shows the XRD patterns of these cast samples. It is clear that a glassy single phase is formed in the samples of 1 and $1.5 \mathrm{~mm}$ in diameter, while crystalline phases are formed for the $2 \mathrm{~mm}$ rod. We have also confirmed the absence of a microscale crystalline phase in the optical micrographs taken from the transverse cross section of the $1 \mathrm{~mm}$ and $1.5 \mathrm{~mm}$ rod samples. Figure 6 shows the DSC curves of the bulk rod samples. It is seen that there is no significant difference in $T_{\mathrm{g}}$ and $T_{\mathrm{x}}$ between the $1 \mathrm{~mm}$ and $1.5 \mathrm{~mm}$ bulk samples. The thermal properties are also similar to those for the amorphous ribbon.

Figure 7 shows the compressive stress-elongation curve of the $\mathrm{Ti}_{20} \mathrm{Zr}_{20} \mathrm{Hf}_{20} \mathrm{Cu}_{20} \mathrm{Ni}_{20}$ bulk glassy alloy with a diameter of $1.5 \mathrm{~mm}$. The glassy alloy exhibits elastic elongation of about $1.7 \%$, followed by plastic elongation of about $0.3 \%$ and then final fracture. The compressive fracture strength $\left(\sigma_{\mathrm{f}}\right)$ 


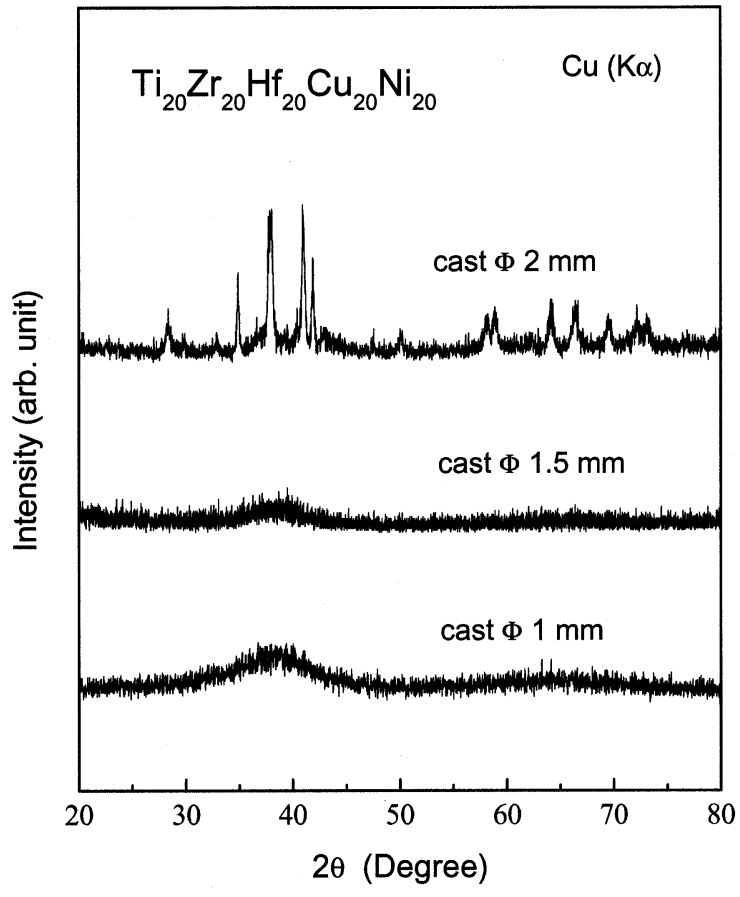

Fig. 5 XRD patterns of cast $\mathrm{Ti}_{20} \mathrm{Zr}_{20} \mathrm{Hf}_{20} \mathrm{Cu}_{20} \mathrm{Ni}_{20}$ rod samples.

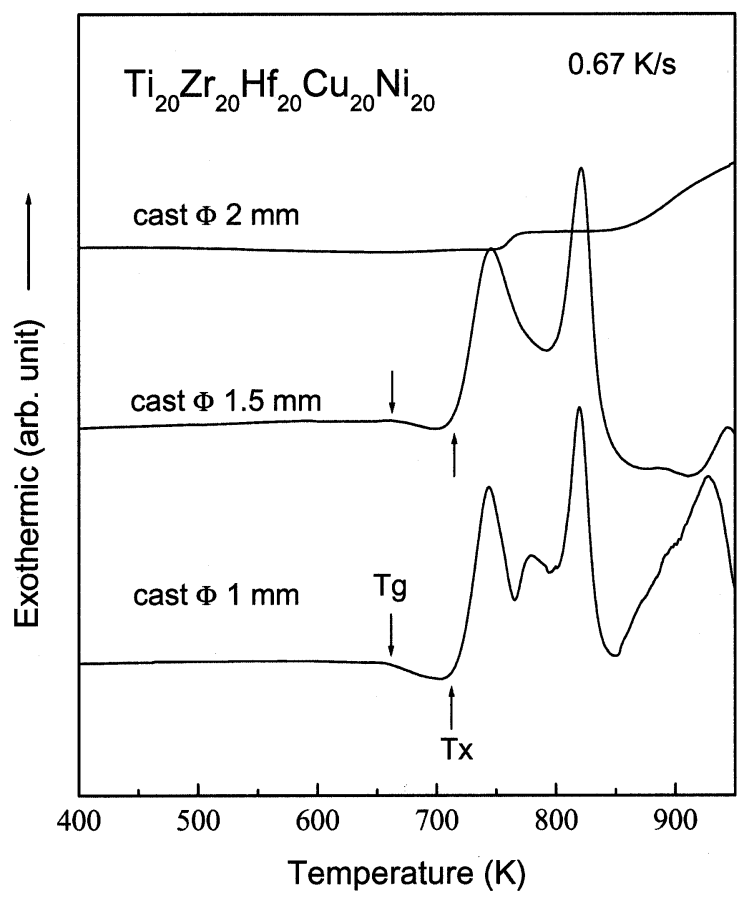

Fig. 6 DSC curves of cast $\mathrm{Ti}_{20} \mathrm{Zr}_{20} \mathrm{Hf}_{20} \mathrm{Cu}_{20} \mathrm{Ni}_{20}$ rod samples.

is $1920 \mathrm{MPa}$ and the Young's modulus $(E)$ is $104 \mathrm{GPa}$. The fracture surface consisted of a developed vein pattern. The fracture occurred along the maximum share plane which was declined by about 54 degrees to the direction of applied load. Vickers hardness of the bulk glassy alloy was 495 . The resulting ratios of $\sigma_{\mathrm{f}} / E$ and $(9.8 \mathrm{Hv}) / 3 \mathrm{E}$ are 0.0185 and 0.0156 , respectively, in agreement with the previous data of ordinary glassy alloys.

The reason why the $\mathrm{Ti}_{20} \mathrm{Zr}_{20} \mathrm{Hf}_{20} \mathrm{Cu}_{20} \mathrm{Ni}_{20}$ alloy has higher glass-forming ability as compared with the $\mathrm{Fe}-$ or $\mathrm{Co}-$ containing alloys may be explained by using the above-

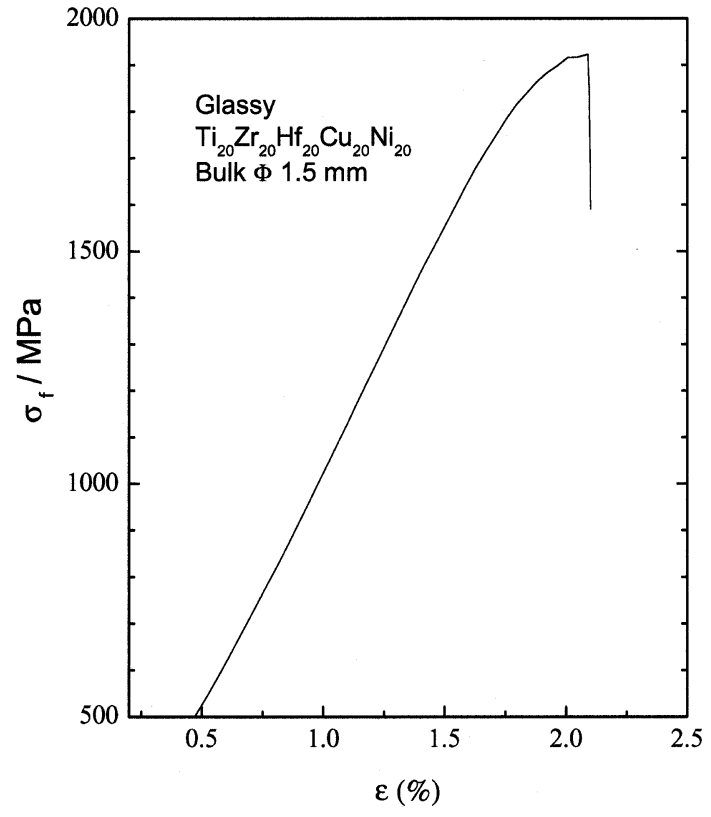

Fig. 7 Compressive stress-elongation curve of the $1.5 \mathrm{~mm}$ bulk $\mathrm{Ti}_{20} \mathrm{Zr}_{20} \mathrm{Hf}_{20} \mathrm{Cu}_{20} \mathrm{Ni}_{20}$ glassy alloy.

Table 1 Heats of mixing $(\mathrm{KJ} / \mathrm{mol})$ among the elements in the $\mathrm{Ti}_{20} \mathrm{Zr}_{20} \mathrm{Hf}_{20} \mathrm{Cu}_{20} \mathrm{M}_{20}(\mathrm{M}=\mathrm{Fe}, \mathrm{Co}, \mathrm{Ni})$ system.

\begin{tabular}{rrrrrrrr}
\hline & \multicolumn{1}{c}{$\mathrm{Ti}$} & \multicolumn{1}{c}{$\mathrm{Zr}$} & \multicolumn{1}{c}{ Hf } & \multicolumn{1}{c}{$\mathrm{Cu}$} & \multicolumn{1}{c}{$\mathrm{Fe}$} & $\mathrm{Co}$ & \multicolumn{1}{c}{$\mathrm{Ni}$} \\
\hline $\mathrm{Ti}$ & & 0 & 0 & -9 & -17 & -28 & -35 \\
$\mathrm{Zr}$ & 0 & & 0 & -23 & -25 & -41 & -49 \\
$\mathrm{Hf}$ & 0 & 0 & & -17 & -24 & -35 & -42 \\
$\mathrm{Cu}$ & -9 & -23 & -17 & & 13 & 6 & 4 \\
$\mathrm{Fe}$ & -17 & -25 & -24 & 13 & & & \\
$\mathrm{Co}$ & -28 & -41 & -35 & 6 & & & \\
$\mathrm{Ni}$ & -35 & -49 & -42 & 4 & & & \\
\hline
\end{tabular}

described three empirical rules. The present alloy system has equal concentration of constituent elements and does not include any main host component. All the heats of mixing in this system are listed in Table 1. All elements of Fe, Co and $\mathrm{Ni}$ have negative heats of mixing against $\mathrm{Ti}, \mathrm{Zr}$ and $\mathrm{Hf}$ and their absolute values for $\mathrm{Ni}$ with $\mathrm{Ti}, \mathrm{Zr}$ and $\mathrm{Hf}$ are larger than those for $\mathrm{Fe}$ or $\mathrm{Co}$ with $\mathrm{Ti}, \mathrm{Zr}$ and $\mathrm{Hf}$. On the other hand, the heats of mixing between $\mathrm{M}$ and $\mathrm{Cu}$ are positive and their values are smaller for $\mathrm{Ni}-\mathrm{Cu}$ pair than for $\mathrm{Co}-\mathrm{Cu}$ and $\mathrm{Fe}-\mathrm{Cu}$ pairs. Table 2 has summarizes the atomic size ratios among the elements in the present system. The atomic size ratios among $\mathrm{Ti}, \mathrm{Zr}$ and $\mathrm{Hf}$ are less than $10 \%$. The atomic size ratios for $\mathrm{Fe}, \mathrm{Co}$ and $\mathrm{Ni}$ with $\mathrm{Ti}, \mathrm{Zr}$ or $\mathrm{Hf}$ are larger than $12 \%$. The atomic size ratios for $\mathrm{Fe}, \mathrm{Co}$ and $\mathrm{Ni}$ with $\mathrm{Cu}$ are much smaller than $12 \%$. Therefore, the larger negative heats of mixing for $\mathrm{Ni}$ with $\mathrm{Ti}, \mathrm{Zr}$ and $\mathrm{Hf}$ should be the main reason for the formation of the bulk glassy $\mathrm{Ti}_{20} \mathrm{Zr}_{20} \mathrm{Hf}_{20} \mathrm{Cu}_{20} \mathrm{Ni}_{20}$ alloy. The atomic size ratios in the present system seems to be the secondary factor for the formation of the bulk glassy alloy.

Here, it is interesting to describe that the bulk glassy state has been obtained in the $\mathrm{Ti}_{20} \mathrm{Zr}_{20} \mathrm{Hf}_{20} \mathrm{Cu}_{20} \mathrm{Ni}_{20}$ alloy without Al. It has been pointed out from structure analyses that $\mathrm{Al}$ element plays an important role in the glassforming ability of the $\mathrm{Zr}-\mathrm{Al}-\mathrm{TM}$ (TM=transition metals) al- 
Table 2 Atomic size ratios (\%) among the elements in the $\mathrm{Ti}_{20} \mathrm{Zr}_{20} \mathrm{Hf}_{20} \mathrm{Cu}_{20} \mathrm{M}_{20}(\mathrm{M}=\mathrm{Fe}, \mathrm{Co}, \mathrm{Ni})$ system.

\begin{tabular}{rrrrrrrr}
\hline & Ti & Zr & Hf & Cu & Fe & Co & Ni \\
\hline $\mathrm{Ti}$ & & 10 & 9 & 15 & 19 & 18 & 18 \\
$\mathrm{Zr}$ & 10 & & 1 & 27 & 31 & 30 & 30 \\
$\mathrm{Hf}$ & 9 & 1 & & 25 & 29 & 28 & 28 \\
$\mathrm{Cu}$ & 15 & 27 & 25 & & 3 & 2 & 2 \\
$\mathrm{Fe}$ & 19 & 31 & 29 & 3 & & & \\
$\mathrm{Co}$ & 18 & 30 & 28 & 2 & & & \\
$\mathrm{Ni}$ & 18 & 30 & 28 & 2 & & & \\
\hline
\end{tabular}

loys. ${ }^{14)}$ The long-range rearrangement of $\mathrm{Al}$ atoms around $\mathrm{Zr}$ atoms is necessary in the crystallization process of the glassy $\mathrm{Zr}-\mathrm{Al}-\mathrm{TM}$ alloys. No bulk glassy phase has been obtained for the $\mathrm{Zr}_{60} \mathrm{Cu}_{20} \mathrm{Ni}_{20}$ alloy. However, the use of $\mathrm{Ti}_{20} \mathrm{Zr}_{20} \mathrm{Hf}_{20} \mathrm{Cu}_{20} \mathrm{Ni}_{20}$ alloy can produce a bulk glassy rod with a diameter of $1.5 \mathrm{~mm}$ in the absence of $\mathrm{Al}$ addition. It is again confirmed from this result that more multicomponent glassy systems can exhibit higher glass-forming ability as compared with simple alloy systems. The relatively high glass-forming ability of the present $\mathrm{Ti}-\mathrm{Zr}-\mathrm{Hf}-\mathrm{Cu}-\mathrm{Ni}$ alloy may be attributed to the formation of a new kind of supercooled liquid with a high degree of dense random packing density, new short-range atomic configurations and longrange atomic interactions which agree with the features of the other ordinary bulk glassy alloys.

\section{Summary}

We have searched for a new bulk glassy alloy in which that each concentration of constituent elements is not over 20 at $\%$. The use of $\mathrm{Ti}_{20} \mathrm{Zr}_{20} \mathrm{Hf}_{20} \mathrm{Cu}_{20} \mathrm{Ni}_{20}$ alloy produced a bulk glassy alloy rod with a diameter of $1.5 \mathrm{~mm}$. The difference between $T_{\mathrm{x}}$ and $T_{\mathrm{g}}$ was $53 \mathrm{~K}$ and $T_{\mathrm{g}} / T_{\mathrm{m}}$ was 0.57 . The compressive fracture strength was $1920 \mathrm{MPa}$ and Vickers hardness was 495. The present glassy system without distinct host component may provide a new alloy design method of bulk glassy alloys.

\section{Acknowledgments}

One of the authors (Liqun Ma) gratefully acknowledges the Japanese Society for the Promotion of Science (JSPS) for providing financial support to carry out the present work.

\section{REFERENCES}

1) A. Inoue, T. Zhang and T. Masumoto: Mater. Trans., JIM 30 (1989) 965-972.

2) A. Inoue, K. Ohtera, K. Kita and T. Masumoto: Jpn. J. Appl. Phys. 27 (1988) L2248-L2251.

3) A. Inoue, T. Zhang and T. Masumoto: Mater. Trans., JIM 31 (1990) 177-183.

4) A. Inoue, T. Zhang, N. Nishiyama, K. Ohba and T. Masumoto: Mater. Lett. 19 (1994) 131-135.

5) A. Inoue and G. S. Gook: Mater. Trans., JIM 36 (1995) 1180-1182.

6) A. Inoue, N. Nishiyama and T. Matsuda: Mater. Trans., JIM 37 (1996) 181-184.

7) X. M. Wang and A. Inoue: Mater. Trans., JIM 41 (2000) 539-542.

8) T. Itoi and A. Inoue: Mater. Trans., JIM 41 (1999) 1256-1262.

9) A. Inoue, W. Zhang, T. Zhang and K. Kurosaka: Mater. Trans. 42 (2001) 1149-1151.

10) A. Inoue: Bulk Amorphous Alloys, (Trans. Tech. Publications, Zurich, 1998) pp. 1-36.

11) A. Inoue, T. Zhang and T. Masumoto: J. Non-Cryst. Solids 156-158 (1993) 473-480.

12) A. L. Greer: Nature 366 (1993) 303-304.

13) P. J. Desre: Mater. Trans., JIM 38 (1997) 583-588.

14) E. Matsubara, T. Tamura, Y. Waseda, T. Zhang, A. Inoue and T. Masumoto: J. Non-Cryst. Solids 150 (1992) 873. 